\title{
Bacterial Blight of Ficus elastica Caused by Xanthomonas ${ }^{1}$
}

\author{
E. V. Campoverde and A. J. Palmateer ${ }^{2}$
}

\section{Introduction}

Florida has led the nation in the production of foliage plants, accounting for more than $55 \%$ of the national wholesale value since the 1960s. Species of Ficus are common ornamental foliage plants used for interior decoration and in landscapes throughout warm climates in South Florida. Ficus species used as foliage plants include $F$. altissima, F. benjamina, F. binnedijkii, F. elastica, F. lyrata, F. microcarpa, F. pumila, F. retusa, and F. rubiginosa, among others (Chen, Henny, and McConnell 2002).

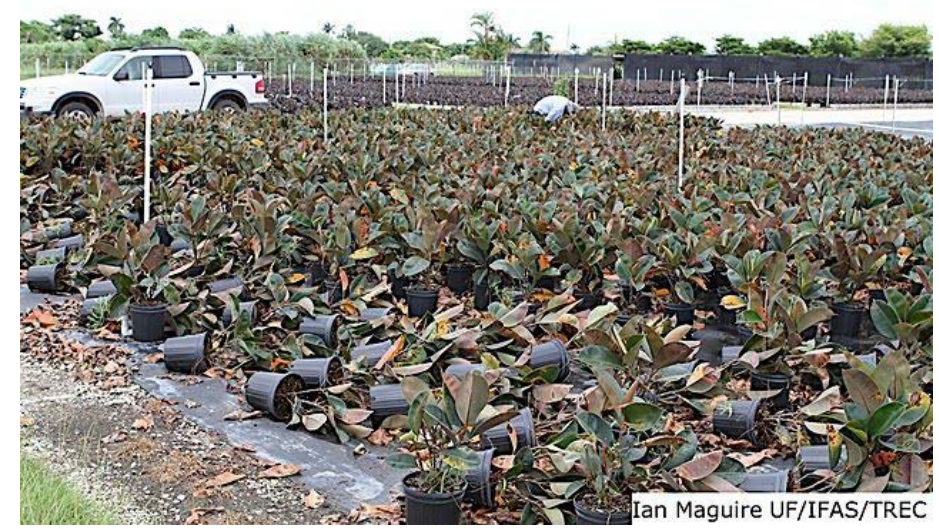

Figure 1. Xanthomonas blight has had a huge economic impact on Ficus elastica nurseries (July 2010).

Credits: Ian Maguire, UF/IFAS
In the summer of 2010, leaf blight cases were reported on several Ficus elastica cultivars in Homestead nurseries. Symptoms somewhat resembled those caused by Xanthomonas campestris p.v. fici, but this pathogen has never been reported to occur on Ficus elastica. The outbreak was severe, and the majority of commercial producers in the southern portion of the state (i.e., Miami-Dade, Broward, and Palm Beach Counties) were affected. The widespread outbreak from 2010 to date has caused many nurseries to lose entire Ficus elastica crops (Campoverde and Palmateer 2011) (Figure 1).

\section{Symptoms}

Xanthomonas species are bacterial plant pathogens that enter plants through wounds or natural openings, such as stomata (breathing pores) or hydathodes. Once the bacterium's cells enter the plant, they can move systemically, causing severe leaf blight. Initial symptoms appear as small, water-soaked, circular lesions with irregular borders near the leaf margin (Figure 2). The water-soaked leaf areas can be readily observed by examining the underside of the leaves (Figure 3). After 7-14 days of initial symptoms, lesions enlarge, coalesce, and typically cover large portions of the leaf area. Eventually, the lesions turn brown with greenish-yellow borders, resulting in premature senescence and leaf drop (Figures 4 and 5).

1. This document is PP305, one of a series of the Plant Pathology Department, Florida Cooperative Extension Service, Institute of Food and Agricultural Sciences, University of Florida. Original publication date April 2013. Visit the EDIS website at http://edis.ifas.ufl.edu.

2. E. V. Campoverde, Extension agent, Miami-Dade County Extension; and A. J. Palmateer, assistant professor of plant pathology, Tropical Research and Education Center, Homestead, FL; Florida Cooperative Extension Service, University of Florida Institute of Food and Agricultural Sciences, Gainesville, FL 32611. 


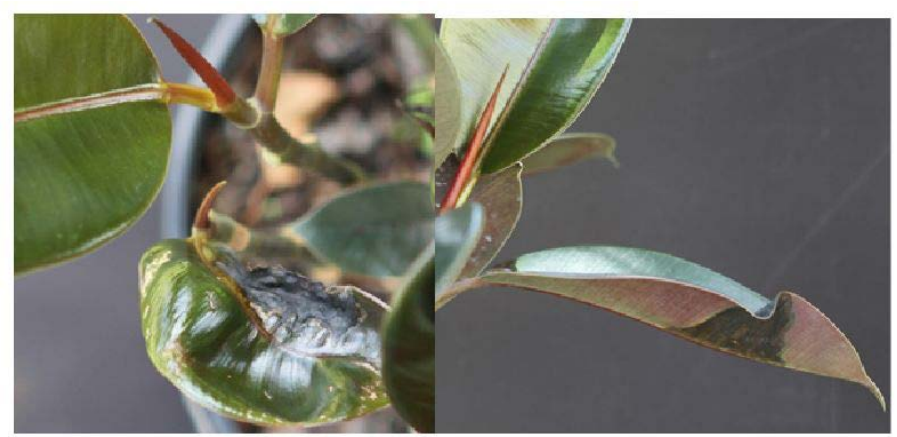

Figure 2. Xanthomonas leaf spot on Ficus elastica'Burgundy'. Left: Necrotic lesion on new growth. Right: Side view of water-soaked lesion on F. elastica.

Credits: Vanessa Campoverde

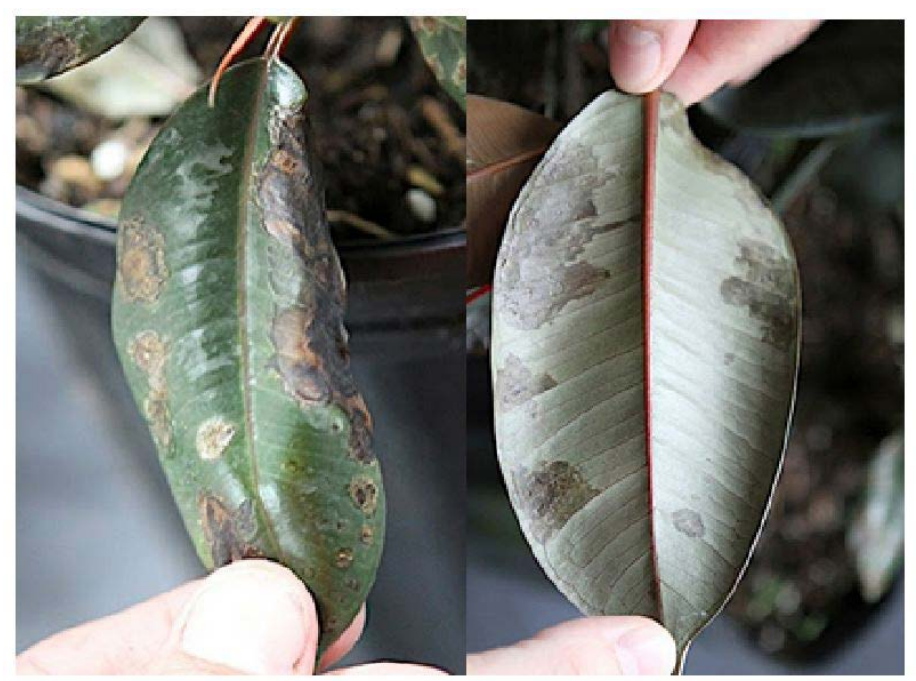

Figure 3. Classic symptoms on older leaves showing on both sides of Ficus leaf.

Credits: Vanessa Campoverde

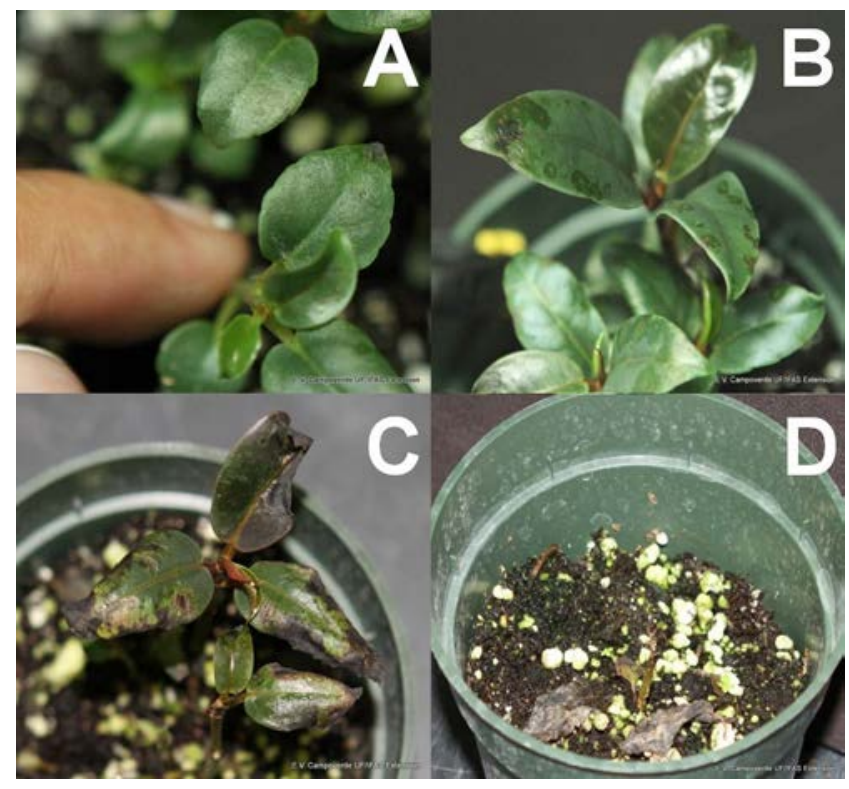

Figure 4. Ficus elastica plant inoculated with Xanthomonas showing disease progress. (A) Local lesions after 7 days. (B) Water-soaked lesions after 10 days. (C) Necrosis symptoms. (D) Death, 21 days after inoculation.

Credits: Vanessa Campoverde

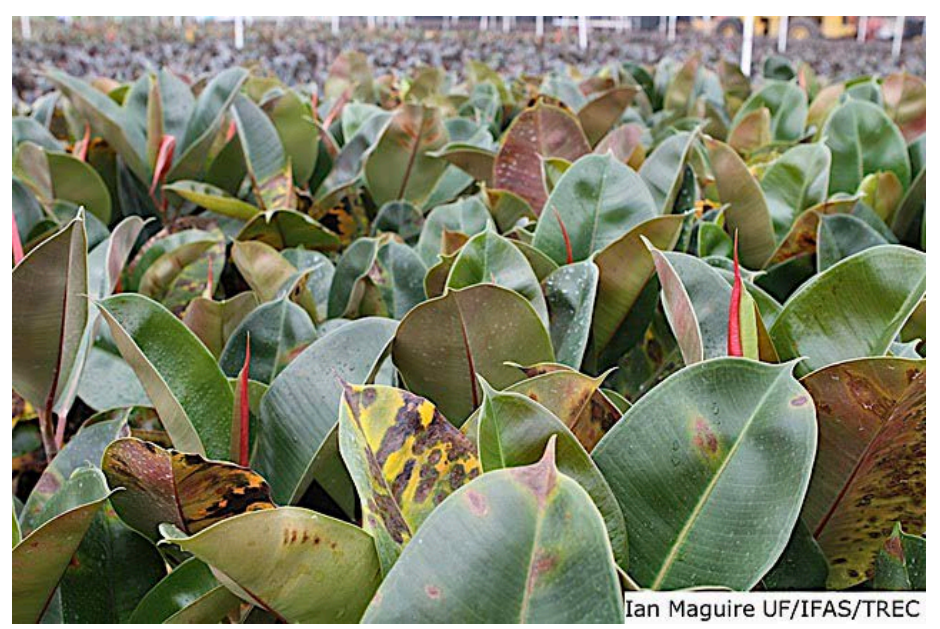

Figure 5. High incidence and severity of Xanthomonas blight on $F$. elastica.

Credits: Ian Maguire, UF/IFAS

\section{Pathogen and Host Range}

Xanthomonas campestris pathovar fici is reported to be the most common bacterial disease affecting Ficus. Host studies indicate that several Ficus species and their cultivars are susceptible to this pathogen, including F. benjamina, F. buxifolia, F. triangularis, F. mexicana, F. maclellandii 'Alli', F. retusa 'California Nitida' and 'Green Gem', and F. Grennisland (Chase and Henley 1993). The Xanthomonas isolates collected from diseased leaves of F. elastica have been tentatively identified as Xanthomonas axonopodis. Molecular characterization of the 16S rDNA exhibited 99\% nucleotide identity to an isolate of $X$. axonopodis (GenBank accession No. AF123091).

Bacterial blight on F. elastica appears to affect plants at all stages and is capable of killing young plants (i.e., liner stage). Host range studies conducted at the UF/IFAS Tropical Research and Education Center (TREC) indicated that several economically important cultivars, including 'Burgundy', 'Robusta', and 'Cabernet', are equally susceptible to the disease. In addition to causing disease on F. elastica, inoculation studies have concluded that F. microcarpa 'Green Island', Strelitzia reginae 'Orange Bird of Paradise', Cordyline terminalis 'Red Ti', and Syngonium podophyllum are all susceptible hosts for Xanthomonas axonopodis.

\section{Disease Management}

Prior to this disease outbreak, F. elastica was a relatively easy plant to grow, requiring minimal use of pesticides for disease management. With bacterial diseases, a preventative disease management approach is the best option (Figure 5). The only way to confirm the presence of Xanthomonas blight on Ficus is to submit samples to a plant disease diagnostic laboratory. Contact your local UF/IFAS Extension agent for assistance. Successfully managing bacterial 
pathogens requires a long-term strategy and actions that focus on changing and improving procedures and materials to reduce the opportunity for spread or reintroduction of the pathogen.

\section{Monitor incoming plants}

If buying from other locations, inspect new liners and plants upon delivery. Any new plants brought into the nursery should be kept isolated (also isolate tools and continuous bench space used for these new plants) from other plants for at least 3-4 weeks to observe any disease or pest symptoms and to avoid contamination with other crops. Do not forget about other potential contamination surfaces, like plant transport trailers or cart surfaces.

\section{Scouting for early symptom development}

Bacteria are readily spread by wind, splashing water, contaminated bedding mix, diseased plants, and on the surface of materials (i.e., pots, pruning tools, etc.). Plant propagation is a particularly vulnerable type of production because young, tender plants and optimal propagation conditions favor disease development. If you suspect an unhealthy or diseased Ficus, contact your local UF/IFAS Extension agent for an accurate diagnosis.

\section{Maintain a disease-free environment}

Sanitation is the key!

Disinfect tools when pruning plants. Bleach (sodium hypochlorite), which works by oxidizing or destroying the molecular bonds in fungi and lysing cells of bacteria, is used in a $10 \%$ concentration. Avoid mixing bleach with acids because toxic chlorine gas may result. Always use with good ventilation.

Store new pots in sanitized areas similar to the soil storage area. Your best option is to always use new potting containers, but if this is not feasible, submerge potting containers in a 1:3 ratio of bleach to water with agitation for a minimum of 10 minutes.

Try to use only unopened potting soil and store on a covered, paved surface that can be periodically washed down with a 1:3 ratio of bleach to water.

\section{Water management}

If possible, use a microjet or drip irrigation system. These systems do not allow water to touch the foliage, which can lead to bacterial spread.
Monitor irrigation and avoid watering late in the day or evenings. If using overhead irrigation, water in the morning so that the foliage has time to dry before evening. Allowing the foliage to dry reduces bacterial spread.

\section{Chemical control}

Pesticides (i.e., fungicides and bactericides) are of limited value in managing bacterial diseases. However, they are your primary defense in prevention and, if used judiciously, they can be effective. Refer to the Professional Disease Management Guide for Ornamental Plants (http://edis.ifas. ufl.edu/pp123) for information about general pesticides used for managing diseases of ornamental plants.

\section{Literature Cited}

Campoverde, E. V., and A. J. Palmateer. 2011. "A Severe Outbreak of Xanthomonas on Ficus elastica in South Florida." Proc. Fla. State Hort. Soc. 124: 321-322

Chase, A. R., and R. W. Henley. 1993. "Susceptibility of Some Ficus Species and Cultivars to Xanthomonas." Southern Nursery Digest 27 (6): 20-21.

Chen, J., R. J. Henny, and D. B. McConnell. 2002. "Development of New Foliage Plant Cultivars." In Trends in New Crops and New Uses, edited by J. Janick and A. Whipkey, 466-472. Alexandria, VA: ASHS Press. 